\title{
Research on the Innovation of Practical Teaching System of Financial Management Major Based on "Four in One"
}

\author{
Dongchuan Lin \\ Sichuan Agricultural University \\ Chengdu, China \\ Chen Ying \\ Sichuan Agricultural University \\ Chengdu, China \\ Jingxue Zhang \\ Sichuan Agricultural University \\ Chengdu, China
}

\author{
Manyu Wang* \\ Sichuan Agricultural University \\ Chengdu, China \\ *Corresponding Author \\ Jinzhong Li \\ Sichuan Agricultural University \\ Chengdu, China \\ Shanxiang Liang \\ Sichuan Agricultural University \\ Chengdu, China
}

\begin{abstract}
On the basis of reviewing the current situation, problems and reforms of practical teaching in financial management major, this paper combines with the implementation of the talent strategy of finance and accounting industry and the integration of production and education of the Ministry of Education, it puts forward the construction of a four-in-one practical teaching system, and deeply analyzes its characteristics, puts forward a targeted implementation strategy finally.
\end{abstract}

Keywords-"four in one"; combination of teaching and competition; innovation and entrepreneurship; collaborative education

\section{INTRODUCTION}

The results of theoretical research and the feedback from employers both show that there is a problem of "heavy theory, light practice" and inadequate innovation and poor implementation in the teaching of financial management, which makes the contradiction between the supply side of talents and the demand side of the industries prominent. Therefore, it is necessary to take the initiative to adapt to the implementation of the talents strategy, the change of industrial demand and the requirements of the national vocational education reform, and to implement the reform of the practical teaching system of the financial management (vocational education) and optimize the training mode of the talents.

\section{LITERATURE REVIEW}

Financial management is very theoretical and practical. So practical teaching is an important part of personnel training. However, by comparing the practical needs of employment and practical teaching in colleges and universities, present educational condition emphasizes theory and underestimates practice (Aie Li, 2017). The educational concept which bases on theory and supplements with practice affects the quality of practical teaching (Aiqin Li et al., 2016). On the one hand, colleges and universities do not invest enough in professional software and infrastructure (Di $\mathrm{Li}, 2012$ ). On the other hand, it is difficult for students to involve in the business operation scene because traditional practical teaching is limited by conditions (Yayun Sun, 2015). Meanwhile, practical teaching and assessment methods are single. Teachers always focus on results evaluation but lack systematic control of the whole process of practical teaching (Lili Huang, 2011). The shortcomings of the teaching and examination mode are not conducive to the cultivation of students' application ability (Xudan Zhen, 2016). Therefore, the reform of financial management practical teaching is particularly necessary.

"Three-dimensional" practical teaching focus on the enterprise financial management post ability as the main line, the professional level, practice time and space are organically combined, integrates "teaching, learning, practice" as a whole(Tong Ye, 2016). The innovative practical teaching module is divided into experimental module, training module and internship module. The link of modules and the progression of content produce synergy effects (Lijia Chen, 2017). With the continuous promotion of "Internet plus", the financial sharing service gradually becomes mature. Therefore, designing the operational module of the financial sharing service platform is conducive to enriching the practical teaching of financial management 
(Min Ni, 2017). It is also an important measure to design a practical teaching system by building a three-in-one education system of "innovative education, simulation practice and project arena" (Yunchen Wang et al, 2017).

According to the experts and scholars' researches, we found that the teaching of financial management shows the present situation of "emphasizing theory and neglecting practice". Practice teaching reform has accumulated experience in three-dimensional, modular, trinity teaching methods and increased financial sharing practice teaching content. However, the research contents focus on teaching contents or the teaching methods. It lacks the systematic research on the interaction between contents and methods, especially the research on deepening the integration of production and education to carry out practical teaching, and building a systematic practice teaching system

\section{THE NECESSITY OF PRACTICAL TEACHING REFORM OF FINANCIAL MANAGEMENT MAJOR}

\section{A. The Requirements of the Times of Accounting Industry Development and Application-oriented Major Construction}

Whether it is "National Program for Medium and Longterm Talent (2010 - 2020)", "Long-term Talent Development Planning in Accounting Industry (2010 to 2020)" or "The Outline of the 13th Five-Year Plan for Accounting Reform and Development (2016)" all proposed to develop urgently needed talents in key areas of economic and social fields such as finance and accounting from different angles. They clearly demand to implement the strategy of financial accounting talents vigorously, and propose to cultivate applied talents through the accounting strategic alliance of industry, education and research. The "13th Five-Year Plan for National Education Development" issued in January 2017 proposes to continue the pilot reform of vocational education at the undergraduate level, promoting the vocational education model which is the integration of production and education, and focuses on the training of application skills and innovative entrepreneurial ability. The "Several Opinions on Deepening the Integration of Industry and Education" issued at the end of 2017 advocates the organic connection of education chain, talent chain, industry chain and innovation chain.

\section{B. The Disadvantages of Traditional Teaching Are Highlighted}

The traditional training system put more emphasis on knowledge transferring than ability training, and weakens thought education; neglects extracurricular practice training and lacks in-depth cooperation with industry organizations. Besides, it lacks the concepts of "promote teaching by competition, promote learning by competition, and promote construction by competition", and lacks the corresponding institutional arrangements and mechanism design. Resulting failure to meet the needs of the society for talent application and poor professionalism.
Traditional courses neglect innovative education. The content of lectures deeply relies on "teaching material". The teaching method is single, the assessment method is rigid, the research courses of speculative and methodological study are few, the research projects of exploratory and interest are lack, and the cultivation of students' innovation and entrepreneurship is insufficient.

\section{THE "FOUR-IN-ONE" PRATICAL TEACHING REFORM DESIGNED FOR FINANCIAL MANAGEMENT MAJOR}

\section{A. Design Concept}

This paper chooses the talent training link that is the most crucial to deepen the integration of production and education in the financial management major and cultivate students' ability of application - practical teaching as the research object. It strives to build a unified "four modules" practical education system based on "experiment, internship, competition, innovation and entrepreneurship", and realizes the four objectives of "knowledge, thinking, ability and quality" to serve the purpose of financial management innovation and application-oriented personnel training. The design is based on the latest national innovative vocational education policy, the talent strategy of the finance and accounting, the industrial demand and the teaching practical experience, researches the reform and practice of the applied financial management professionals' practical teaching system. From the perspective of the practical community, it builds up a practical education system including the multiparty participation of "school-association-enterprisesoftware service providers". The design is dedicated to explore the path to realize the cultivation of undergraduate innovative applied talents in financial management specialty (vocational education) by the mechanism of "integration of production and education, collaborative education".

\section{B. Design Features}

The design has the following three characteristics: (1) The construction of the practical education system is an important way to build a collaborative education mechanism. (2) The concept of "four-in-one" runs through the whole practical teaching and talent cultivation. (3) The "four goals" in the practical education system rely on the effective connection of "four modules" in order to achieve coordinated development and play a synergistic effect.

\section{Design Significance}

This design has certain practical significance for improving the quality of practical teaching, students' competitiveness, professional influences and social contributions. Meanwhile, it can provide reference experience for other colleges and universities to apply professional construction and deepen the integration of production and education, and promote the construction of collaborative educational mechanism. Specifically, the design is suitable for providing talent training programs, practical teaching implementation programs for accounting, economic management professional leaders, deepening integration of production and education in colleges and 
universities, improving the collaborative education mechanism, and building applied professional programs. Providing reference for the education authorities to formulate policies such as entrepreneurial vocational education and applied undergraduate talent strategy.

\section{V. "FOUR-IN-ONE" PRACTICE TEACHING REDOEM STRATEGY}

\section{A. Experimental Module}

We should Firmly establish the concept of consolidating theoretical knowledge, and training basic skills by software simulation experiment to build a professional experiment module. On the one hand, we must increase the investment of experimental software, including the introduction cooperative development of new software, upgrade traditional software; On the other hand, the experimental content should be carried out in a hierarchical manner. The professional basic courses, professional courses, and core backbone courses have different emphasis on experimental time, teaching methods, and training content, but they can be connected to each other.

\section{B. Internship Module}

Constructing a "two-dimensional three-level" internship system, that is, horizontally constructing a "schoolassociation-enterprise" mechanism of "integration of production and education, collaborative education"; vertically constructing a "professional practice-post practicegraduation internship" progressive internship system. Specifically, the core business professional practice includes financial information and decision analysis, financial case analysis, accounting professional practice, audit professional practice, etc.; post practice is concentrated on the rotation practice at internship bases ; graduation internship is combined with graduation thesis and employment agreement .

We focus on internship base, gradually improving construction of platform. With the establishment of schoolenterprise cooperation mechanism, enterprises can participate in the talent training system of colleges, so that students can meet their job ability requirements when they graduate, thus effectively reducing the human resource costs of enterprises. With the establishment of school-enterprise partnerships, effective resource sharing can be achieved between universities and enterprises.

\section{Competition Module}

We implement a combination of teaching and learning to build a support platform for professional competence practice. We combine daily teaching, curriculum construction, practice links, etc. with professional competitions to build a reasonable professional competition platform, explore and practice teaching methods of "simulation management, scene teaching", "interest-leading, research competition projects" and "road show competitions", etc., and form a stable model of "warm-up, training, selection in the school match, and actual combat, training, and talented at off-campus competition, "Establishing corresponding competition incentive mechanism, and giving full play to the enthusiasm of the instructors and participating students are very important too. The competition includes three categories: internal competition of professional skills promotion, regional competition or national competition and management comprehensive competition. Among them, the school's professional skills competition focuses on the regional competition, national competition, such as accounting skills competition, financial decision-making competition. The comprehensive competition focuses on the integration of its management expertise, such as the enterprise operation sand table simulation competition and the enterprise value creation competition.

\section{Innovation Entrepreneurship Module}

1) Firmly establishing a scientific concept of innovation
and entrepreneurship education: Innovative
entrepreneurship education is an intrinsic requirement and proper meaning for improving the quality of undergraduate professional training in financial management. The professional talent training program is revised, and the spirit of innovation, entrepreneurial awareness and innovation and entrepreneurship are taken as important indicators for evaluating the quality of personnel training; Entrepreneurship credit accumulation and conversion system, recognized as a credit for entrepreneurship courses after attending the SYB training organized by the school.

2) Constructing a three-dimensional theoretical curriculum system based on innovation and entrepreneurship: The curriculum system will be set up into three major sections: financial management professional courses, innovative thinking training courses and entrepreneurial courses; vigorously promote the reform of curriculum teaching, optimize the content modules of professional basic courses such as Management, concentrate on building professional core courses, and increase entrepreneurship. Innovative and entrepreneurial courses such as "Entrepreneurship Management" and "Centre Case Analysis", the content and online courses of selected business lectures are supplemented and extended. For example, CCTV "Combat Business School" and other courses are introduced into the classroom, focusing on professional course teaching and innovation and entrepreneurship education.

3) Building a "three platforms" for innovation and entrepreneurship: The "three platforms" is the first platform of the enterprise operation virtual simulation experiment center, the second platform of the entrepreneurship incubation center for business students and the third platform of the innovation and entrepreneurial competition coordination guidance center. The first platform focuses on the improvement of students' professional ability and innovative ability. The second platform focuses on the improvement of students' entrepreneurial ability, and also 
takes into account the improvement of students' innovative ability. The third platform focuses on students' ability to innovate and start their own businesses. The third platform focuses on promoting students' innovation and entrepreneurship, it is the supplement of the first platform and the second platform. The three platforms are organically combined to aim to develop students' comprehensive ability to highlight innovation and entrepreneurship.

Relying on the three-platform innovation and entrepreneurship training program, we will introduce outstanding innovation and entrepreneurship competitions at home and abroad such as the enterprise management elite competition, "three creation competition", "challenge cup", "creation roadshow contest", and establish the collaborative guidance center for innovation and entrepreneur competition. In addition, we will select the backbone teachers, set up the guiding team, form an intellectual support platform, and adopt the "1 plus N" training method, that is, $\mathrm{N}$ teachers guide one team to realize the goal management of the student team training and guiding project.

\section{CONCLUSION}

In view of the practical teaching dilemma of financial management major and the reality of application-oriented major construction. Under the guidance of the Ministry of Education's concept of "integration of production and education, collaborative education", this paper explores the "Four-In-One" practical teaching system of financial management major, and has put forward specific measure based on the four modules of experiment, practice, competition, innovation and entrepreneurship. The research has certain practical significance to alleviate the contradiction between the supply side of talents and the demand side of the industry due to the financial management major practice teaching innovation. The implementation of the design needs to be carried out by creating a teaching community, and the effect of the implementation needs to be tested. Therefore, the design also needs to be further improved according to the actual situation.

\section{ACKNOWLEDGEMENT}

This paper is supported by the Scientific Research Fund of Sichuan Vocational and Technical Education Center (NO. GZY18C51), the key Project of Undergraduate Education and Teaching Reform Research of Sichuan Agricultural University in 2017(NO. X2017023) and the funding of the Discipline Construction and the Academic Team Construction Program of Sichuan Agricultural University.

\section{REFERENCES}

[1] Li Ai'e. Research on Teaching Reform of Financial Management Specialty from the Perspective of Applied Talents Training [J]. Cultural and Educational Materials, 2017 (13): 180-181.

[2] Li Aiqin, Gong Xueru, Ma Jin. A Summary of the Research on Undergraduate Practical Teaching of Financial Management in Colleges and Universities in China [J].Tibet Education, 2016(05):4549.
[3] Li Di. Analysis on the Reform of Practical Teaching of Financial Management Specialty in Applied Undergraduate Universities [J]. Business Economics, 2012(24): 116-117.

[4] Sun Yayun. Practical Teaching Innovation of Financial Management Course Based on Simulated Entrepreneurship [J]. Journal of Fujian Commercial College, 2015(02): 68-73.

[5] Huang Lili. Research on Undergraduate Professional Practical Teaching in Financial Management [J].Friends of Accounting, 2011(18): 118-119.

[6] Zheng Xudan. Research on the Training Mode of Financial Management Professionals in Applied Undergraduate Colleges[J]. Education Modernization, 2016(30): 15-17.

[7] Ye Wei, Duan Hua, You Jinyong. Research on the "ThreeDimensional" Practical Teaching Reform of "Financial Management" Courses in Colleges and Universities in China $[\mathrm{J}]$. Science and Education Wenhui (first issue), 2016 (01): 65-66.

[8] Chen Lijia. Research on the Practical Teaching System of Applied Undergraduate Financial Management Specialty [J]. Modern Business and Industry, 2017(12): 138-139.

[9] Ni Min. Research on Practice Teaching Reform of Financial Management Specialty Based on Financial Sharing Service Model[J]. Journal of Jilin Engineering and Technology Teachers College, 2017(02): 47-59.

[10] Wang Yunchen, Zeng Xiangrui, Liu Juan, Tang Manping, Fu Gang, Luo Huawei. Research on the Training Model of Financial Management Talents Oriented by the Innovation and Entrepreneurial Ability Improvement [J].Commercial Accounting,2017(07):114-117. 